\title{
Neurotropic viruses and cerebral palsy: population based case-control study
}

Catherine S Gibson, Alastair H Maclennan, Paul N Goldwater, Eric A Haan, Kevin Priest, Gustaaf A Dekker, for the South Australian Cerebral Palsy Research Group

\begin{abstract}
Objective To investigate the association between cerebral palsy and direct evidence for perinatal exposure to neurotropic viruses.

Design Population based case-control study.

Setting Adelaide Women's and Children's Hospital Research Laboratory.

Participants and main outcome measures Newborn screening cards of 443 white case patients with cerebral palsy and 883 white controls were tested for viral nucleic acids from enteroviruses and herpes viruses by using polymerase chain reaction. Herpes group A viruses included herpes simplex viruses 1 and 2 (HSV-1 and HSV-2), Epstein-Barr virus (EBV), cytomegalovirus (CMV), and human herpes virus 8 (HHV-8), and herpes group $\mathrm{B}$ viruses included varicella zoster virus (VZV) and human herpes viruses 6 and 7 (HHV-6 and HHV-7). Results The prevalence of viral nucleic acids in the control population was high: $39.8 \%$ of controls tested positive, and the prevalence was highest in preterm babies. The detection of herpes group B viral nucleic acids increased the risk of developing cerebral palsy (odds ratio 1.68, 95\% confidence interval 1.09 to 2.59 ).

Conclusions Perinatal exposure to neurotropic viruses is associated with preterm delivery and cerebral palsy.
\end{abstract}

\section{Introduction}

Intrauterine infection is postulated to be an important contributor to the development of cerebral palsy. ${ }^{1-3}$ Previous studies have investigated surrogate markers of infection, such as chorioamnionitis, funisitis, maternal pyrexia, raised values of $\mathrm{C}$ reactive protein, and raised interleukin- 6 concentrations. ${ }^{4}$ This research used molecular techniques to show the presence of viral nucleic acids in the blood of newborn babies.

The herpes viruses (including cytomegalovirus (CMV), herpes simplex viruses 1 and 2 (HSV-1 and HSV-2), varicella zoster virus (VZV), Epstein-Barr virus (EBV), and human herpes viruses 6, 7, and 8 (HHV-6, HHV-7, and HHV-8), and enteroviruses can all cross the placenta and infect the fetus. ${ }^{5-10}$ These viruses are potentially neurotropic and could contribute directly or indirectly to the causation of cerebral palsy. The likelihood of maternal infection resulting in infection of the fetus varies according to the specific virus, whether the infection is primary or recurrent, and the gestational age of the fetus at the time of infection. For cytomegalovirus, the risk of transmission to the fetus for mothers with primary infection is $50 \%$, but only a minority $(<1 \%)$ of mothers with reactivation (or reinfection) transmit the virus in utero. ${ }^{11}$ Once the infection has crossed the placenta into the fetal circulation, the potential for neuronal damage is there, directly and also by the fetal inflammatory response in which pro-inflammatory cytokines may affect the developing brain adversely. This combination of factors may determine who develops cerebral palsy.

Some viruses can persist for months or years after the initial infection. ${ }^{12-15}$ These viruses may have effects as long as 30 years after the original infection. ${ }^{16}$

We investigated associations between potentially neurotropic viruses and cerebral palsy in a white Australian population. Our hypothesis was that evidence of perinatal viral infection may be associated with the development of cerebral palsy.

\section{Methods}

\section{Selection of patients and controls}

The study population comprised all children with cerebral palsy born in 1986-99 in South Australia to white mothers $(\mathrm{n}=443)$, ascertained by South Australia's cerebral palsy register. The controls were 883 babies born to white mothers from 1986 to 1999. ${ }^{17}$ We identified newborn screening cards from South Australia's newborn screening programme for each case and control. We selected four potential controls from screening cards filed (by date of receipt) before $(n=2)$ and after $(n=2)$ the cards of cases. The date of birth of each control baby was within a few days of the case baby, the hospital from which we took the screening cards was of the same category (metropolitan teaching, metropolitan private, or country), and we took samples on roughly the same day of life as for the cases. The control population included a higher proportion of preterm infants than the general population, as many of the cases of cerebral palsy were born preterm and had been referred to metropolitan teaching hospitals. Linkage (with Automatch, version 4.3, Kennebunk, USA, 1998), using South Australia's perinatal database, was successful for all cases and 1691 controls. To ensure that they were not potentially cases of cerebral palsy we excluded $268 / 1691(15.8 \%)$ controls because they were children of non-white mothers $(n=102)$, had a birth defect notified to the state's birth defects register $(n=161)$, or died in the first year of life $(n=37)$. We excluded some controls for more than one reason. Random numbers were used to select two controls from the remaining controls in each group of four, to form the control population of 886 . As three controls had been selected more

A table showing prevalences of neurotropic viruses in a population of newborns diagnosed with cerebral palsy is on bmj.com 
than once, the final number of controls was 883 . These samples were not randomly selected from the entire newborn population; they were therefore representative of a white population without cerebral palsy, infant death, or notifiable birth defects. The data from all cases and controls were required to be de-identified before testing for polymorphisms and viral nucleic acids and statistical analysis. We undertook all testing with blinding to case or control status.

\section{Virus detection}

The viruses of interest were categorised into DNA and RNA viruses. The DNA viruses included HSV-1, HSV-2, VZV, EBV, CMV, HHV-6, HHV-7, and HHV-8. The RNA viruses included members of the Enterovirus family. We used two polymerase chain reactions to detect DNA viruses, using previously published primers. ${ }^{18}$ We assigned results to the respective test groups: the first detected nucleic acids of HSV-1, HSV-2, EBV, $\mathrm{CMV}$, and $\mathrm{HHV}-8$, hereafter designated herpes group $\mathrm{A}$, and the second detected nucleic acids of VZV, HHV-6, and HHV-7, hereafter designated herpes group B. Within group A, differentiation between CMV and the remaining viruses (HSV-1, HSV-2, EBV, and HHV-8) was possible because of differences in band sizes of products from the polymerase chain reaction, which were visually determined by agarose gel electrophoresis.

We used NucleoSpin Tissue Extraction Kit (Macherey-Nagel, Germany) to extract punches of dried blood $(1.2 \mathrm{~mm})$ on newborn screening cards (collected by heel prick at 3-5 days of life) for DNA viruses. We chose a phenolic wash method to extract the newborn screening cards for RNA. ${ }^{19}$

We used reference RNA and DNA samples extracted from viral stocks to optimise all conditions for amplification. We included these reference samples as positive controls for all subsequent amplifications, using dried blood spots in addition to negative (no template) controls.

\section{Sensitivity of virus detection}

We determined the minimum number of detectable viral nucleic acid copies for each polymerase chain reaction and extrapolated back to a minimum number of detectable viral nucleic acid copies per millilitre of blood. The minimum number of detectable viral nucleic acid copies was $2.8 /$ bloodspot $\left(5.6 \times 10^{3} / \mathrm{ml}\right.$ blood $)$ for enterovirus, $1.6 /$ bloodspot $\left(3.2 \times 10^{3} / \mathrm{ml}\right.$ blood $)$ for herpes group A viruses, and $15 /$ microlitre $\left(3.2 \times 10^{3} / \mathrm{ml}\right.$ blood) for herpes group $\mathrm{B}$ viruses.

\section{Statistical analysis}

We detected these viral nucleic acids by using newborn screening samples that had been stored for up to 18 years. We used PEPI, version 4.0 (Sagebrush Press, Salt Lake City, USA, 2001) to calculate prevalence proportions and exact 95\% confidence intervals of the viruses in the newborn screening cards tested.

As cases and controls had not been matched for covariates such as gestational age, we used all controls in our analysis. Data analysis (GraphPad Instat, version 3.06, San Diego, USA) then considered cerebral palsy cases and controls by gestational age range ( $<37$ weeks, $\geq 37$ weeks, and all gestational ages), type of cerebral palsy (diplegia, hemiplegia, quadriplegia, and all types) and virus. Results are expressed as odds ratios with 95\% confidence intervals, comparing positive with negative virus detection. $\mathrm{P}$ values below 0.05 are marked in the tables.

\section{Results}

Results were obtained from a total of 414/443 cerebral palsy samples $(93.5 \%)$ and 856/883 control samples $(96.9 \%)$, a differ-
Table 1 Prevalence of neurotropic viral nucleic acids, from individual viruses or groups of viruses, in stored neonatal blood spots from a control population of South Australian newborns without cerebral palsy, expressed as percentage positive of the total tested

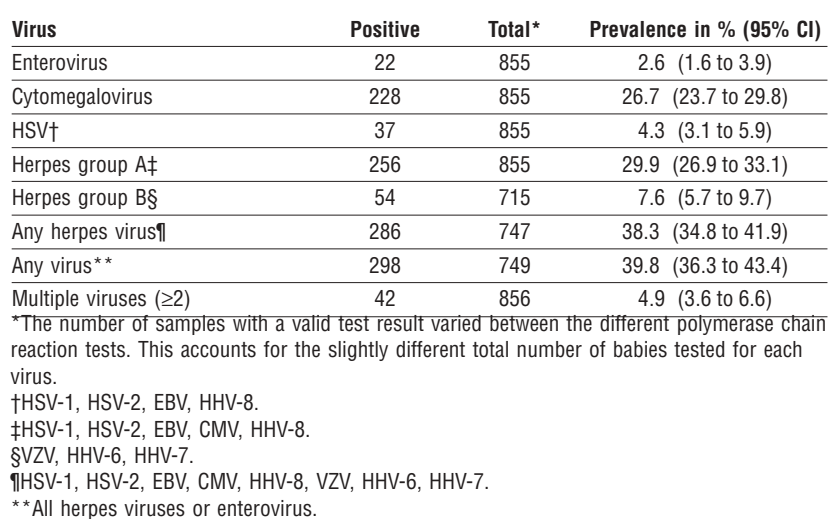

ence that may cause an underestimation of the prevalence of viral exposure in the cerebral palsy cases (odds ratio 2.22, 95\% confidence interval 1.26 to 3.93). Not all viruses gave a clear result for each card; the total number of results for each virus was therefore less than the maximum totals of 414 for cases or 856 for controls. The results are expressed as total readable results.

\section{Prevalence of viruses in control population}

We determined the prevalence of viral nucleic acids in the newborn white population of South Australia without cerebral palsy (table 1). CMV was the most prevalent virus, with 228 babies $(26.7 \%)$ testing positive. In addition, 42 babies $(4.9 \%)$ were positive for more than one virus. Of the babies positive for multiple viruses, the most common combination observed was herpes group B and CMV, with a prevalence of $3.1 \%$ (1.9 to 4.6), followed by CMV and herpes group A, with a prevalence of $1.1 \%$ (0.5 to 2.1). The remainder of the virus combinations contributed very small numbers, with prevalences of less than $1 \%$.

We investigated the effect of gestational age on the prevalence of these viruses because of the high rate of prematurity in the control population. CMV was significantly $(\mathrm{P}<0.01)$ more prevalent in preterm $(82 / 247)$ than term $(146 / 608)$ babies (33.2\% and $24.0 \%$, respectively; odds ratio $1.57,95 \%$ confidence interval 1.14 to 2.17; table 2). Herpes group A viruses were also significantly $(\mathrm{P}<0.05)$ more prevalent in preterm $(89 / 247)$ than term $(167 / 608)$ babies $(36.0 \%$ and $27.5 \%$, respectively; $1.49,1.09$ to 2.04). The same trend was observed for the presence of any herpes virus, with 44.3\% (98/221) of preterm babies testing positive for any herpes virus, compared with $35.7 \%$ (188/526) of term babies $(1.43,1.04$ to 1.97 ; table 2$)$. No other virus was significantly different in relation to gestational age. The difference in the prevalences of any of the viruses between very preterm babies of less than 32 weeks' gestation and preterm babies of 32-36 weeks' gestation did not reach significance.

\section{Viruses and cerebral palsy}

We investigated associations between neurotropic viruses and cerebral palsy, taking into consideration gestational age and subtypes of cerebral palsy. Of the 414 cases of cerebral palsy, 131 were diagnosed with diplegia, 119 with hemiplegia, 112 with quadriplegia, and 52 with other or unspecified subtypes.

\section{All gestational ages}

The primary analyses showed a significant association between any viral exposure and cerebral palsy at all gestational ages (1.30, 
Table 2 Prevalence of neurotropic viral nucleic acids, from individual viruses or groups of viruses, in stored neonatal blood spots from a control population of term and preterm South Australian newborns without cerebral palsy, expressed as percentage positive of the total tested

\begin{tabular}{|c|c|c|c|c|}
\hline $\begin{array}{l}\text { Virus and gestation in } \\
\text { weeks }\end{array}$ & Positive & Total† & $\begin{array}{l}\text { Prevalence in \% } \\
\quad(95 \% \mathrm{CI})\end{array}$ & Odds ratio $(95 \% \mathrm{Cl})$ \\
\hline \multicolumn{5}{|l|}{ Enterovirus } \\
\hline$\geq 37$ & 17 & 608 & 2.8 (1.6 to 4.4$)$ & Reference \\
\hline$<37$ & 5 & 247 & 2.0 (0.7 to 4.7) & 0.72 (0.26 to 1.97$)$ \\
\hline \multicolumn{5}{|l|}{ Cytomegalovirus } \\
\hline$\geq 37$ & 146 & 608 & 24.0 (20.7 to 27.6) & Reference \\
\hline$<37$ & 82 & 247 & 33.2 (27.4 to 39.4) & $1.57(1.14 \text { to } 2.17)^{*}$ \\
\hline \multicolumn{5}{|l|}{ HSV¥ } \\
\hline$\geq 37$ & 29 & 608 & 4.8 (3.2 to 6.8$)$ & Reference \\
\hline$<37$ & 8 & 247 & 3.2 (1.4 to 6.3$)$ & 0.67 (0.30 to 1.48$)$ \\
\hline \multicolumn{5}{|l|}{ Herpes group A§ } \\
\hline$\geq 37$ & 167 & 608 & 27.5 (24.0 to 31.2$)$ & Reference \\
\hline$<37$ & 89 & 247 & 36.0 (30.0 to 42.4$)$ & $1.49(1.09 \text { to } 2.04)^{\star \star}$ \\
\hline \multicolumn{5}{|l|}{ Herpes group В } \\
\hline$\geq 37$ & 39 & 503 & 7.8 (5.6 to 10.4) & Reference \\
\hline$<37$ & 15 & 212 & 7.1 (4.0 to 11.4) & 0.91 (0.49 to 1.68$)$ \\
\hline \multicolumn{5}{|l|}{ Any herpes virust† } \\
\hline$\geq 37$ & 188 & 526 & 35.7 (31.6 to 40.0$)$ & Reference \\
\hline$<37$ & 98 & 221 & 44.3 (37.7 to 51.2) & $1.43(1.04 \text { to } 1.97)^{\star *}$ \\
\hline \multicolumn{5}{|l|}{ 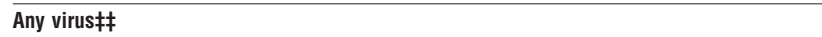 } \\
\hline$\geq 37$ & 199 & 528 & 37.7 (33.5 to 42.0$)$ & Reference \\
\hline$<37$ & 99 & 221 & 44.8 (38.1 to 51.6) & 1.34 (0.98 to 1.84$)$ \\
\hline
\end{tabular}

Odds ratios (95\% confidence intervals) for $<37$ weeks' gestation compared with $\geq 37$ weeks' gestation.

${ }^{*} \mathrm{P}<0.01$ compared with prevalence in babies born at term. ${ }^{* *} \mathrm{P}<0.05$ compared with prevalence in babies born at term.

†The number of samples with a valid test result varied between the different polymerase chain reaction tests. This accounts for the slightly different total number of babies tested for each virus.

łHSV-1, HSV-2, EBV, HHV-8.

$\S \mathrm{HSV}-1, \mathrm{HSV}-2$, EBV, CMV, HHV-8.

IVZV, HHV-6, HHV-7.

t+ HSV-1, HSV-2, EBV, CMV, HHV-8, VZV, HHV-6, HHV-7.

ł‡All herpes viruses or enterovirus.

1.00 to 1.67$)$. The detection of herpes group B viral nucleic acids increased the risk of developing all types of cerebral palsy, with an odds ratio of 1.68 (1.09 to 2.59). This increased risk was also observed for the diplegic (1.93, 1.03 to 3.61$)$ and hemiplegic $(2.07,1.10$ to 3.88$)$ subtypes of cerebral palsy and herpes group $\mathrm{B}$ viruses. Associations did not reach significance for any of the other viruses.

\section{Gestational age $\geq 37$ weeks}

The risk of developing cerebral palsy for a gestational age of 37 weeks or more increased with the detection of any herpes virus, with an odds ratio of 1.52 (1.09 to 2.13), and also with the detection of any virus $(1.64,1.17$ to 2.28$)$. Herpes group $B$ viruses were associated with the development of diplegia (2.45, 1.02 to 5.89 ) and hemiplegia $(2.38,1.15$ to 4.92$)$. The risk of developing cerebral palsy for gestational age of 37 weeks or more increased with the detection of any herpes virus (1.52, 1.09 to 2.13) and also with the detection of any virus (1.64, 1.17 to 2.28). Associations did not reach significance for any of the other viruses (table 3).

\section{Gestational age $<37$ weeks}

The detection of herpes group A viral nucleic acids decreased the risk of developing all types of cerebral palsy for gestational age $<37$ weeks $(0.65,0.43$ to 0.99 ; table 4$)$. Detection of herpes group $\mathrm{B}$ increased the risk for quadriplegia for gestational age $<37$ weeks $(2.87,1.09$ to 7.59$)$. We found no other significant associations for any of the other viruses (table 4).
Table 3 Odds ratios (with 95\% confidence intervals) for specified viruses in babies with cerebral palsy at $\geq 37$ weeks' gestation compared with controls at $\geq 37$ weeks' gestation

\begin{tabular}{|c|c|c|c|c|}
\hline irus & $\begin{array}{l}\text { All types of } \\
\text { cerebral palsy } \\
(n=227)\end{array}$ & $\begin{array}{c}\text { Diplegia } \\
(\mathrm{n}=49)\end{array}$ & $\begin{array}{l}\text { Hemiplegia } \\
(n=81)\end{array}$ & $\begin{array}{l}\text { Quadriplegia } \\
\qquad(n=65)\end{array}$ \\
\hline $\operatorname{HSV}(10)^{*}$ & $\begin{array}{c}0.92 \\
(0.44 \text { to } 1.92)\end{array}$ & $\begin{array}{c}0.85 \\
(0.20 \text { to } 3.67)\end{array}$ & $\begin{array}{c}1.04 \\
(0.35 \text { to } 3.03)\end{array}$ & 0.31 (0.04 to 2.33 ) \\
\hline$\overline{\mathrm{CMV}}($ & $\begin{array}{c}1.30 \\
(0.92 \text { to } 1.83) \\
\end{array}$ & $\begin{array}{c}1.03 \\
\text { (0.52 to } 2.02) \\
\end{array}$ & $\begin{array}{c}1.04 \\
(0.61 \text { to } 1.78) \\
\end{array}$ & 1.62 (0.94 to 2.80$)$ \\
\hline $\begin{array}{l}\text { Herpes group B } \\
(23) \dagger\end{array}$ & $\begin{array}{c}1.69 \\
(0.98 \text { to } 2.92)\end{array}$ & $\begin{array}{c}2.45 \\
(1.02 \text { to } 5.89) \ddagger\end{array}$ & $\begin{array}{c}2.38 \\
\text { (1.15 to } 4.92) \ddagger\end{array}$ & $\begin{array}{c}0.00 \\
(0.00 \text { to } 0.89) \ddagger\end{array}$ \\
\hline $\begin{array}{l}\text { Herpes group A } \\
\text { (73)§ }\end{array}$ & $\begin{array}{c}1.25 \\
(0.90 \text { to } 1.74)\end{array}$ & $\begin{array}{c}0.95 \\
(0.49 \text { to } 1.84)\end{array}$ & $\begin{array}{c}1.11 \\
(0.67 \text { to } 1.85)\end{array}$ & 1.45 (0.84 to 2.48$)$ \\
\hline $\begin{array}{l}\text { Any herpes virus } \\
(88) \pi\end{array}$ & $\begin{array}{c}1.52 \\
\text { (1.09 to 2.13)‡ }\end{array}$ & $\begin{array}{c}1.41 \\
\text { (0.74 to } 2.67) \\
\end{array}$ & $\begin{array}{c}1.38 \\
\text { (0.83 to } 2.30) \\
\end{array}$ & 1.25 (0.71 to 2.20$)$ \\
\hline Enterovirus (10) & $\begin{array}{c}1.63 \\
(0.74 \text { to } 3.62)\end{array}$ & $\begin{array}{c}1.55 \\
(0.35 \text { to } 6.90)\end{array}$ & $\begin{array}{c}1.83 \\
(0.60 \text { to } 5.58)\end{array}$ & $1.12(0.25$ to 4.97$)$ \\
\hline Any virus $(96)^{\star \star}$ & $\begin{array}{c}1.64 \\
(1.17 \text { to } 2.28) \ddagger\end{array}$ & $\begin{array}{c}1.58 \\
\text { (0.83 to } 2.98)\end{array}$ & $\begin{array}{c}1.43 \\
(0.86 \text { to } 2.37)\end{array}$ & $1.29(0.7$ \\
\hline
\end{tabular}

Numbers of positive test results for each virus for cases of cerebral palsy are listed in parentheses in the first column.

${ }^{*} H S V-1, H S V-2$, EBV, HHV-8.

+VZV, HHV-6, HHV-7.

$\ddagger$ Significant at the 0.05 level.

$\S H S V-1$, HSV-2, EBV, CMV, HHV-8.

१HSV-1, HSV-2, VZV, EBV, CMV, HHV-6, HHV-7, HHV-8.

${ }^{* *}$ All herpes viruses or enterovirus.

\section{Combination viruses at any gestational age}

The presence of more than one virus was not associated with the risk of developing cerebral palsy at any gestational age (1.13, 0.65 to 1.98). Comparing term born babies with cerebral palsy with term born controls $(1.29,0.64$ to 2.61$)$, or preterm babies with cerebral palsy with preterm controls $(0.98,0.38$ to 2.53$)$, did not show any associations either.

\section{Discussion}

Perinatal exposure to and infection with viruses are associated with cerebral palsy in the newborn. Our findings reinforce the possibility of a complex and heterogeneous relation between exposure to viral infections and subtypes of cerebral palsy at dif-

Table 4 Odds ratios (with 95\% confidence intervals) for specified viruses in babies with cerebral palsy at $<37$ weeks' gestation compared with controls at $<37$ weeks' gestation

\begin{tabular}{|c|c|c|c|c|}
\hline Virus & $\begin{array}{c}\text { All types of } \\
\text { cerebral palsy } \\
(\mathrm{n}=187)\end{array}$ & $\begin{array}{c}\text { Diplegia } \\
(\mathrm{n}=82)\end{array}$ & $\begin{array}{l}\text { Hemiplegia } \\
\qquad(\mathrm{n}=38)\end{array}$ & $\begin{array}{l}\text { Quadriplegia } \\
\quad(n=47)\end{array}$ \\
\hline $\operatorname{HSV}(3)^{*}$ & $\begin{array}{c}0.49 \\
\text { (0.13 to } 1.87)\end{array}$ & $\begin{array}{c}0.17 \\
(0.00 \text { to } 1.75)\end{array}$ & $\begin{array}{c}0.37 \\
(0.00 \text { to } 3.85)\end{array}$ & $\begin{array}{c}1.33 \\
(0.27 \text { to } 6.46)\end{array}$ \\
\hline CMV (49) & $\begin{array}{c}0.72 \\
(0.47 \text { to } 1.10)\end{array}$ & $\begin{array}{c}0.88 \\
\text { (0.51 to } 1.51)\end{array}$ & $\begin{array}{c}0.72 \\
(0.33 \text { to } 1.55)\end{array}$ & $\begin{array}{c}0.61 \\
(0.30 \text { to } 1.27)\end{array}$ \\
\hline $\begin{array}{l}\text { Herpes group B } \\
(17) \dagger\end{array}$ & $\begin{array}{c}1.73 \\
\text { (0.83 to } 3.59)\end{array}$ & $\begin{array}{c}1.67 \\
\text { (0.65 to } 4.30)\end{array}$ & $\begin{array}{c}1.41 \\
\text { (0.38 to } 5.17)\end{array}$ & $\begin{array}{c}2.87 \\
\text { (1.09 to } 7.59) \ddagger\end{array}$ \\
\hline $\begin{array}{l}\text { Herpes group A } \\
(50) \S\end{array}$ & $\begin{array}{c}0.65 \\
(0.43 \text { to } 0.99) \ddagger\end{array}$ & $\begin{array}{c}0.78 \\
\text { (0.46 to } 1.33)\end{array}$ & $\begin{array}{c}0.63 \\
(0.29 \text { to } 1.37)\end{array}$ & $\begin{array}{c}0.54 \\
(0.26 \text { to 1.12) }\end{array}$ \\
\hline $\begin{array}{l}\text { Any herpes virus } \\
(61) \Re\end{array}$ & $\begin{array}{c}0.82 \\
\text { (0.54 to } 1.25) \\
\end{array}$ & $\begin{array}{c}0.99 \\
\text { (0.57 to 1.71) }\end{array}$ & $\begin{array}{c}0.66 \\
\text { (0.30 to 1.43) }\end{array}$ & $\begin{array}{c}0.84 \\
(0.42 \text { to } 1.66)\end{array}$ \\
\hline Enterovirus (3) & $\begin{array}{c}0.79 \\
\text { (0.19 to } 3.35)\end{array}$ & $\begin{array}{c}0.27 \\
\text { (0.01 to } 4.89 \text { ) }\end{array}$ & $\begin{array}{c}1.31 \\
\text { (0.15 to } 11.52)\end{array}$ & $\begin{array}{c}2.15 \\
\text { (0.40 to } 11.44)\end{array}$ \\
\hline ny virus $(64)^{\star \star}$ & $\begin{array}{c}0.88 \\
(0.58 \text { to } 1.33)\end{array}$ & $\begin{array}{c}0.97 \\
\text { (0.56 to } 1.68)\end{array}$ & $\begin{array}{c}0.74 \\
(0.34 \text { to } 1.59)\end{array}$ & $\begin{array}{c}1.01 \\
\text { (0.51 to 1.99) }\end{array}$ \\
\hline
\end{tabular}

Numbers of positive test results for each virus for $\mathrm{CP}$ cases are listed in parentheses in the first column.

${ }^{*} \mathrm{HSV}-1, \mathrm{HSV}-2, \mathrm{EBV}, \mathrm{HHV}-8$

+VZV, HHV-6, HHV-7.

fSignificant at the 0.05 level.

\&HSV-1, HSV-2, EBV, CMV, HHV-8.

§HSV-1, HSV-2, EBV, CMV, HHV-8.
IHSV-1, HSV-2, VZV, EBV, CMV, HHV-6, HHV-7, HHV-8.

${ }^{*}$ A All herpes viruses or enterovirus. 
ferent gestational ages. Other cofactors may trigger neurotropic damage. We examined the association between cerebral palsy and perinatal exposure to neurotropic viruses. The findings were based on the detection of viral nucleic acids from newborn screening card blood spots collected within a few days of birth, and where detected, the findings indicate intrauterine or early neonatal viral exposure or infection.

\section{Caveats}

Post hoc analyses were performed on the individual viruses and their combinations, increasing the likelihood of identifying chance statistical associations. Because of the small numbers in some of the subanalyses, other associations cannot be excluded with confidence. Where associations are seen in one gestational age range, similar trends are seen in the same subgroup of cerebral palsy with the same virus in other gestational age ranges. This implies that these may indicate true causal relations and may not be attributed to chance. These associations require further study.

\section{Viral associations with preterm birth and cerebral palsy}

We document the prevalence of certain viral nucleic acids in a white control population and have shown that stored neonatal blood spots can be used to investigate associations with cerebral palsy. Exposure to viral nucleic acids seems very common in our control population, with a prevalence of $39.8 \%$ for any of the viruses tested, and these were mostly herpes viruses. Nearly $5 \%$ of our control population tested positive for more than one virus. The prevalence of CMV was significantly higher in those controls born at less than 37 weeks' gestation than in controls born at term $(33.2 \% v 24.0 \%)$, implying that the presence of viral infectious agents in the womb is also associated with subsequent preterm delivery. ${ }^{20-23}$

Using this large cohort of cases of cerebral palsy and controls we identified specific viral DNA and RNA nucleic acid sequences and showed that exposure to viral nucleic acids (and presumably infectious virus), in particular herpes group B, is associated with cerebral palsy. The results show a 1.5-2.5 times increased risk of developing cerebral palsy after perinatal exposure to herpes group B viruses. The prevalence of herpes group B viruses was $7.6 \%$ for controls and $12.1 \%$ for babies with cerebral palsy, giving a potential attributable risk of $4.5 \%$ of all cases of cerebral palsy if a causal relation exists. These results also show an increased risk of developing cerebral palsy in term babies after perinatal exposure to any virus. In contrast, the results from table 4 imply negative associations between perinatal exposure to viral nucleic acids and subsequent cerebral palsy for babies born before term. These conflicting results may be due to the higher prevalence of viral infection in control babies born before term, thus diluting any positive association between viral infection and cerebral palsy for preterm babies. Exposure late in gestation may not result in preterm birth, instead having direct effects on the brain, whereas exposure early in gestation may result in preterm birth but increase the risk of neuropathology associated with prematurity. In this manner, exposure to perinatal viral infection may be indirectly associated with cerebral palsy.

\section{Viral loads}

Although our study used non-quantitative methods of and well documented primers for polymerase chain reaction, viral loads may vary over a wide range. Low viral loads may not be sufficient to precipitate preterm birth, but continuing intrauterine development in the presence of infection may allow the infection to contribute to permanent neuropathology. On the other hand, high viral loads may initiate or result in preterm birth and increase the risk of neurological damage associated with prematurity or infection, or both. We plan prospective studies quantifying viral loads to test this theory. Prospective studies will allow access to a wider range of clinical data and correlation with clinical evidence of infection.

\section{Future directions}

Our results do not necessarily indicate active congenital or neonatal infection. Detection of viral nucleic acids in the blood of neonates indicates only exposure to the respective virus or viruses, and not an inflammatory response. Given the small sample volume and the limit of detection of one to 10 viral nucleic acid copies, it could be inferred that true viraemic infection was occurring. It therefore also seems unlikely that presence of viral nucleic acid merely reflected transfer of maternal cells to the fetal circulation via the placenta. Prospective investigations are required to follow women through pregnancy, testing antenatal maternal blood samples for viral nucleic acids, and umbilical cord blood to determine if there is active infection in the fetus or neonate by examining leukocytes for the presence of viral antigens associated with active viral replication and the presence and severity of the inflammatory response of the fetus. The advent of widespread childhood vaccination against VZV, which has been available in South Australia for 10 years, will provide an opportunity to investigate the impact of maternal VZV infection and reactivation on the development of cerebral palsy. It will be interesting to observe if a decline occurs in the rates of cerebral palsy in the next generation, after the vaccination of their mothers, in a way similar to that of the rubellavirus vaccine in reducing the teratogenic effects of rubella during pregnancy.

\section{Pathogenesis}

It is unclear how perinatal exposure to viral infection causes subsequent brain damage and cerebral palsy. If the virus is able to cross the blood-brain barrier, it is capable of setting up infection in the brain and directly damaging vulnerable neuronal tissue. Herpesviruses are capable of establishing themselves within the brain, where they can remain latent indefinitely or reactivate and cause damage. Alternatively, products of infection can be released locally and into the circulation. These products can cross the blood-brain-barrier, as a result of either the barrier's immaturity ${ }^{24}$ or the release of pro-inflammatory cytokines that impair its integrity. ${ }^{25}{ }^{26}$ Having penetrated the blood-brainbarrier, these pro-inflammatory cytokines-such as tumour necrosis factor $\alpha$-can cause direct damage to developing white matter, resulting in periventricular leukomalacia, with possible stimulation of fetal microglia to produce more TNF- $\alpha^{27}$ and disruption of the endothelium and ependyma. ${ }^{26}$

The high prevalence of exposure to viral infection in our control population indicates that "triggers" or cofactors are needed before brain damage can occur. Such triggers may include genetic susceptibility to infections-for example, cytokine polymorphisms that increase or decrease the host immune response to the infection. Disruption of barriers such as the placenta and blood-brain barrier as a result of fetal infarctions secondary to inherited thrombophilia may also have a role in the transmission and establishment of infections. Infection triggering thrombosis in the fetus with thrombophilia could also be postulated. An association between fetal thrombophilia and cerebral palsy has also been found in our cohort. ${ }^{28}$

\section{Conclusions}

Our study has shown that exposure to viral infection is common in newborn babies in South Australia, especially in preterm babies. The risk of cerebral palsy is nearly doubled with exposure 


\section{What is already known on this topic}

Preterm birth and choriamnionitis are associated with cerebral palsy and infection with neurotropic viruses in neonates and infants can lead to neurological disability, including cerebral palsy

\section{What this study adds}

Stored dried neonatal blood spots, from babies who were diagnosed subsequently to have cerebral palsy, and from control babies, often contain nucleic acids from neurotropic viruses

Herpes group A (including cytomegalovirus) nucleic acids were found more often in neonatal blood spots of preterm control babies than in control babies born at term

Herpes group B nucleic acids were found more often in neonatal blood spots of babies who were diagnosed subsequently to have cerebral palsy than in control babies

The presence of neurotropic viral nucleic acids in the blood of newborns and the subsequent diagnosis of cerebral palsy are significantly associated

to herpes group B viruses but may require other factors, such as genetic susceptibility to infection and inherited thrombophilia or involvement of other clinical events-for example, growth restriction or prematurity-for brain damage and subsequent cerebral palsy to occur. Future studies are planned to investigate these factors.

We thank Barry Slobedman (Westmead Millennium Institute, NSW, Australia) for providing us with positive control viral material.

Contributors: CSG contributed to the collection, analysis and interpretation of data, writing of the manuscript, and is a study guarantor. AHM contributed to the design and interpretation of the data, writing of the manuscript, and is a study guarantor. PNG contributed to the design and interpretation of the data and writing of the manuscript. EAH contributed to the design, collection and interpretation of data, and writing of the manuscript. KP contributed to the collection and analysis of data, and writing of the manuscript. GAD contributed to the design and interpretation of data, and writing of the manuscript, and is a study guarantor. CSG, AHM, and GAD are guarantors. Other members of the South Australian Cerebral Palsy Research Group were involved in design of the study: Annabelle Chan, William M Hague, Zbigniew Rudzki, Phillipa Sharpe, T Yee Khong, Mark R Morton, Enzo Ranieri, Heather Scott, Heather Tapp, and Graeme Casey.

Funding Sources: Australian National Health and Medical Research Council, Channel 7 Children's Research Foundation, University of Adelaide, and South Australian Government Captive Insurance Corporation.

Competing interests None declared.

Ethical approval: Research Ethics Committee of the Women's and Children's Hospital.

1 Grether JK, Nelson KB. Maternal infection and cerebral palsy in infants of normal birth weight. JAMA 1997;278:207-11.

2 Nelson KB, Willoughby RE. Overview: infection during pregnancy and neurologic outcome in the child. Ment Retard Dev Disabil Res Rev 2002;8:1-2.
3 Vigneswaran R, Aitchison SJ, McDonald HM, Khong TY, Hiller JE. Cerebral palsy and placental infection: a case-cohort study. BMC Pregnancy Childbirth 2004;4:1.

4 Yoon BH, Romero R, Park JS, Kim M, Oh SY, Kim CJ, et al. The relationship among inflammatory lesions of the umbilical cord (funisitis), umbilical cord plasma interleukin 6 concentration, amniotic fluid infection, and neonatal sepsis. Am J Obstet Gynecol 2000;183:1124-9.

5 McLean LK, Chehab FF, Goldberg JD. Detection of viral deoxyribonucleic acid in the amniotic fluid of low-risk pregnancies by polymerase chain reaction. Am J Obstet Gynecol 1995; 173:1282-6.

6 Mouly F, Mirlesse V, Meritet JF, Rozenberg F, Poissonier MH, Lebon P, et al. Prenatal diagnosis of fetal varicella-zoster virus infection with polymerase chain reaction of diagnosis of fetal varicella-zoster virus infection with polymer.

7 Palmer AL, Rotbart HA, Tyson RW, Abzug MJ. Adverse effects of maternal enterovirus infection on the fetus and placenta. J Infect Dis 1997;176:1437-44.

8 Brown HL, Abernathy MP. Cytomegalovirus infection. Semin Perinatol 1998;22:260-6.

9 Wenstrom KD, Andrews WW, Bowles NE, Towbin JA, Hauth JC, Goldenberg RL. Intrauterine viral infection at the time of second trimester genetic amniocentesis. Obstet Gynecol 1998;92:420-4.

10 Takami T, Sonodat S, Houjyo H, Kawashima H, Takei Y, Miyajima T, et al. Diagnosis of horizontal enterovirus infections in neonates by nested PCR and direct sequence analysis. J Hosp Infect 2000;45:283-7.

11 Remington JS, Klein JO. Infectious diseases of the fetus and newborn infant. 4th ed. Philadelphia: WB Saunders, 1995.

12 Hammad E, Helin I, Pacsa A. Early pregnancy varicella and associated congenital anomalies. Acta Paediatr Scand 1989;78:963-4.

13 Forouzan I. Fetal abdominal echogenic mass: an early sign of intrauterine cytomegalovirus infection. Obstet Gynecol 1992;80(3 Pt 2):535-7.

14 Huang YC, Lin TY, Wong KS, Chiu CH. Congenital anomalies following maternal varicella infection during early pregnancy.J Formos Med Assoc 1996;95:393-5.

15 Corey RP, Flynn JT. Maternal intrauterine herpes simplex virus infection leading to persistent fetal vasculature. Arch Ophthalmol 2000;118:837-40.

16 O'Neill JF. The ocular manifestations of congenital infection: a study of the early effect and long-term outcome of maternally transmitted rubella and toxoplasmosis. Trans Am Ophthalmol Soc 1998;96:813-79.

17 Gibson CS, MacLennan AH, Rudzki Z, Hague WM, Haan E, Sharpe P, et al. The prevalence of inherited thrombophilias in a Caucasian Australian population. Pathology 2005;37:160-163.

18 Johnson G, Nelson S, Petric M, Tellier R. Comprehensive PCR-based assay for detection and species identification of human herpesviruses. J Clin Microbiol 2000;38:3274-9

19 Rogers CD, Burgoyne LA. Reverse transcription of an RNA genome from databasing paper (FTA(R)). Biotechnol Appl Biochem 2000;31(Pt 3):219-24.

20 Friese K. The role of infection in preterm labour. BJOG 2003;110(suppl 20):52-4.

21 Lamont RF. Infection in the prediction and antibiotics in the prevention of spontaneous preterm labour and preterm birth. Bjog 2003;110(Suppl 20):71-5.

22 Romero R, Chaiworapongsa T, Espinoza J. Micronutrients and intrauterine infection, preterm birth and the fetal inflammatory response syndrome. J Nutr 2003;133(5 suppl 2):1668S-1673S

23 Jacobsson B. Infectious and inflammatory mechanisms in preterm birth and cerebral palsy. Eur J Obstet Gynecol Reprod Biol 2004;115:159-60.

24 Adinolfi M. The development of the human blood-CSF-brain barrier. Dev Med Child Neurol 1985;27:532-7.

25 Megyeri P, Abraham CS, Temesvari P, Kovacs J, Vas T, Speer CP. Recombinant human tumor necrosis factor alpha constricts pial arterioles and increases blood-brain barrier permeability in newborn piglets. Neurosci Lett 1992;148:137-40.

26 Dammann O, Leviton A. Maternal intrauterine infection, cytokines, and brain damage in the preterm newborn. Pediatr Res 1997;42:1-8.

27 Yost NP, Cox SM. Infection and preterm labor. Clin Obstet Gynecol 2000;43:759-67.

28 Gibson CS, MacLennan AH, Hague WM, Haan EA, Priest K, Chan A, et al Association between inherited thrombophilias, gestational age, and cerebral palsy. Am J Obstet Gymecol 2005; 193;1437.

(Accepted 8 October 2005)

doi $10.1136 /$ bmj.38668.616806.3A

University of Adelaide, Women's and Children's Hospital, 1st Floor Queen Victoria Building, 72 King William Road, Adelaide, SA 5006, Australia

Catherine $\mathrm{S}$ Gibson postdoctoral research fellow, Department of Obstetrics and Gynaecology

Alastair H MacLennan professor, Department of Obstetrics and Gynaecology Gustaaf A Dekker professor, Department of Obstetrics and Gynaecology Paul N Goldwater senior consultant clinical microbiologist, Department of Microbiology and Infectious Diseases

Eric A Haan clinical geneticist, Department of Genetic Medicine

Epidemiology Branch, Department of Health, Adelaide, SA 5000, Australia Kevin Priest epidemiologist

Correspondence to: C S Gibson catherine.s.gibson@adelaide.edu.au 